\title{
Memória
}

\section{PROFESSOR SEVERO}

\author{
Ecléa Bosi \\ Universidade de São Paulo, \\ Instituto de Psicologia \\ São Paulo, SP, Brasil.
}

Muitos de nós que estudamos na rua Maria Antônia, onde por tantos anos se sediou a Faculdade de Filosofia, fomos alunos do Professor Severo.

Suas aulas de Estatística, entremeadas de conceitos filosóficos e frases latinas, intimidavam os estudantes. As provas eram o terror: alternativas semelhantes, diabolicamente semelhantes, entre as quais teríamos que escolher a verdadeira. Noites em claro, muitas vezes choro depois da prova. Os fortes na matéria eram poucos, como lara lavelberg, Ana Maria Almeida, Lídia Rosenberg, que ajudavam os colegas em perigo.

Numa certa manhã de abri de 1961 entrei no saguão da Faculdade tomado de grande agitação. Grupos discutiam em altos brados. Aquele local sempre foi a caixa de ressonância de movimentos políticos. Enorme fila se formara e aguardava sua vez diante da mesa posta no saguão.

Fui informada no ato de que Cuba estava na iminência de ser invadida. $O$ governo socialista seria derrubado e Fidel assassinado. $O$ alerta partira de Ernesto Guevara. $O$ ataque teve início na Praia de Girón localizada na Baía dos Porcos. Kennedy assumira havia pouco a presidência, mas a ClA já treinava em Miami os exilados cubanos que para lá fugiram com a queda do ditador Fulgencio Batista. E os equipara com armas modernas. Situação desesperadora para a ilha que na época era a menina dos olhos da esquerda.

A mesa do saguão da Maria Antônia recolhia inscrições de "Voluntários para a defesa da Revolução Socialista". Esses jovens, que nunca tinham segurado armas na mão, queriam embarcar imediatamente dis- 
postos a morrer para enfrentar um exército financiado pelos Estados Unidos. O entusiasmo que nos invadia não era menor que a indignação, mas havia também esperança.

Escutei a meu lado uma voz conhecida:

- Sei que não sou mais jovem, mas ainda posso lutar. Aceitem minha inscrição como voluntário.

Era o professor José Severo de Camargo Pereira.

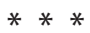

Não perdemos nosso mestre de Estatística na batalha, porque três dias depois os cubanos haviam rechaçado os invasores.

O fim da agressão foi anunciado no Jornal Nacional pelo simpático repórter da época: o poeta Paulo Bonfim, que denunciou o golpe armado em Miami e anunciou a vitória do povo cubano. 